Etnográfica

Revista do Centro em Rede de Investigação em

Antropologia

vol. 17 (1) | 2013

Vol. $17(1)$

\title{
Amor à venda? Ritualizações do programa entre as prostitutas do restaurante Granada
}

Love for sale? Escorting ritualizations among the prostitutes of the Granada restaurant

\section{Ana Paula Luna Sales}

\section{(2) OpenEdition}

\section{Journals}

Edição electrónica

URL: https://journals.openedition.org/etnografica/2609

DOI: 10.4000/etnografica.2609

ISSN: 2182-2891

\section{Editora}

Centro em Rede de Investigação em Antropologia

\section{Edição impressa}

Data de publição: 1 fevereiro 2013

Paginação: 147-163

ISSN: 0873-6561

\section{Refêrencia eletrónica}

Ana Paula Luna Sales, «Amor à venda? Ritualizações do programa entre as prostitutas do restaurante Granada», Etnográfica [Online], vol. 17 (1) | 2013, posto online no dia 13 março 2013, consultado o 09 fevereiro 2022. URL: http://journals.openedition.org/etnografica/2609; DOl: https://doi.org/10.4000/ etnografica.2609

\section{(c) (i) (8)}

Etnográfica is licensed under a Creative Commons Attribution-NonCommercial 4.0 International License. 


\section{Amor à venda? Ritualizações do programa entre as prostitutas do restaurante Granada}

\section{Ana Paula Luna Sales}

Este artigo foi construído a partir da primeira pesquisa etnográfica que realizei, tendo por campo o restaurante Granada, espaço dedicado principalmente à prostituição, localizado no centro de Fortaleza, Ceará, Brasil. Partindo da perspectiva feminina, concentro-me aqui na forma do programa, entendido como o conjunto das relações estabelecidas entre "meninas" (categoria êmica para prostitutas) e clientes. Deste modo, estão em análise seus determinantes espaço-temporais, as práticas corporais que se lhe impõem, as concepções que o cercam. O "programa" é apreendido como um ritual apresentando em seus três momentos (aproximação, conversa e sexo) fortes prescrições que delimitam e contrastam os modos como as "meninas" se relacionam dentro e fora do contexto do Granada.

PALAVRAS-CHAVE: prostituição, programa, ritual.

Love for sale? Escorting ritualizations among the prostitutes of the Granada restaurant - This article is based on my first ethnographic work, which took place at the Granada restaurant, a space mainly dedicated to prostitution practices in downtown Fortaleza, Ceará, Brazil. Taking sides on the female perspective, I focus here on the form of the escort, understood as the ensemble of relationships established between meninas (emic category for prostitutes) and clients. In this sense I analyse the space-time determinants of such relationships, the bodily practices imposed on them and the entailing conceptions. Therefore, escorting is apprehended as a ritual involving in its three phases (approach, talk and sex) strong prescriptions that restrain and contrast the relationship patterns of the meninas inside and beyond Granada's context.

KEYWORDS: prostitution, escort, ritual.

LUNA SALES, Ana Paula (paulalunasales@gmail.com) - École des Hautes Études en Sciences Sociales (EHESS), França. 
ESTE ARTIGO FOI REDIGIDO A PARTIR DA MONOGRAFIA APRESENTADA na conclusão do curso de graduação em Ciências Sociais da Universidade Estadual do Ceará, em 2011 (Luna Sales 2011). ${ }^{1}$ Ele é baseado no seu terceiro capítulo, que se concentra nas ritualizações do "programa" performadas pelas "meninas" do restaurante Granada, um espaço que envolve o restaurante e o motel, chamado pelos seus agentes apenas de "bar", localizado no centro da cidade de Fortaleza, Ceará.

A prática da prostituição feminina no Granada implica certas ações padronizadas, que apesar de não determinadas absolutamente, vão servir de guia para as performances (Strathern 1988; Dawsey 2005) elaboradas pelos atores sociais - não só prostitutas - e relacionadas ao vivenciado dentro deste contexto.

Nessas ações encontram-se elaboradas distinções entre o que é feito (dito, insinuado) com clientes, de um lado, e parceiros (regulares ou esporádicos), de outro. Estas distinções organizam não somente o ato sexual em si, mas tudo o que envolve o "estar" com estes e aqueles. Apesar de, em muitos aspectos, a relação com os "amigos"3 parecer mimetizar a tida com os maridos, namorados e amantes, essa mimese é representada como vazia de desejo romântico-sexual feminino, o que transfigura forma e conteúdo em um "duplo monstruoso" (do amor) no qual "as diferenças não são abolidas, mas embaralhadas e misturadas. Todos os duplos são intercambiáveis, sem que sua identidade seja formalmente reconhecida" (Girard 1990: 201).

Mario Perniola (2000) discute o erotismo como um intermediário poético entre o humano e a divindade, que ao mesmo tempo em que os fará parecer iguais, não permitirá que se esqueça que são essencialmente diferentes, fazendo-me comparar as meninas a essas poetisas eróticas, senhoras do liminar sexo pago.

O processo ritual apareceu-me intuitivamente como ferramenta metodológica adequada para interpretar a prática sexual das prostitutas do Granada, primeiramente por esta ser entendida por elas como algo fora do "normal" ou do estabelecido pela sociedade mais abrangente (Silva 2007), apesar de muitas vezes, em suas vidas, ser mais frequente o encontro com clientes que com parceiros não comerciais. ${ }^{4}$

I Agradeço imensamente ao Prof. Dr. João Tadeu de Andrade, que me orientou não só no processo de construção desta monografia, mas também em minha iniciação nos conceitos e metodologias da antropologia. Sou grata ainda aos demais professores e colegas da Universidade Estadual do Ceará pela atenção e perspicácia das contribuições nos temas aqui abordados.

2 Denominação nativa para prostitutas.

3 Denominação nativa para clientes fixos.

4 Este "normal" aqui visto de acordo com a crença que entende que "[a] sexualidade é, então, cuidadosamente encerrada. Muda-se para dentro de casa. A família conjugal a confisca. E absorve-a, inteiramente, na seriedade da função de reproduzir" (Foucault 1988: 9). 
Bem além disso, porém, o programa, tal como ele é feito pelas meninas do Granada, se insinua como um ritual pelo seu poder organizador quanto às experiências vividas no contexto da prostituição. Mais que encadear ações, as performances das meninas no programa estabelecem um modelo de interação que ultrapassa diferenças individuais, eficaz além dos limites espaço-temporais do encontro (Houseman 2004). Tal modelo de interação reforça as já distintas categorias de cliente e parceiro não comercial, de forma a apartá-las reiteradamente no âmbito das classificações. Consequência disto é a produção de clientes não-homens, destituídos de agência, com os quais não se faz sexo, mas sim programa (Olivar 2011).

No programa, as meninas "cozinham" seus clientes de forma a suprimir a sua parte-homem. Desde a aproximação até o pagamento, a relação estabelecida é aquela própria do consumo cotidiano, que "alimenta" outras socialidades que não aquela com o homem (objetificado) em face de si (Fausto 2002). Por meio da apreensão de si mesmas enquanto um coletivo e da produção (coletiva) de um ritual, a perspectiva das meninas se impóe e faz meros clientes dos homens que frequentam o bar (Castro 1996; Olivar 2011).

Pontuo ainda que o ritual a ser descrito aqui, da forma como o farei, é uma invenção, uma construção antropológica, "encorporada" 5 nos termos desta disciplina; as formulações que as meninas fazem de suas próprias práticas são compreendidas de formas diversas (Strathern 1988). Trata-se de um esquema elaborado a partir de vários depoimentos, muitos deles contraditórios, mas que foi aqui estruturado numa forma una, de modo a representar a tomada de poder de significação por um grupo específico, observada na pesquisa. Este grupo seria o formado por Andrea (não por acaso mencionada primeiro), Nálary, Cassandra e Vítor.

É este o ritual de que falo. O uso deste termo evocará esta ficção antropológica no decorrer da escrita, sem comprometer-me com definições consagradas ou representações das meninas - se fosse lhes perguntado, com certeza elas achariam no mínimo esquisito que eu descrevesse os programas que fazem desta maneira.

Este ritual tem como maior característica a complexidade, porque é condensador de experiências, memórias e representações diversas, mas ao mesmo tempo é simplificador, uma vez que tenta colocar sob a unidade processual tantas ações que ocorreram e tantos significados possíveis, nem todos previstos. A unidade assumida, contudo, não é aleatória. Ela encerra o vivenciado com aquelas meninas que animam no campo a constatação de Gilles Deleuze e Félix Guattari: "Os grupos e os indivíduos contêm microfascismos sempre à espera de cristalização. [...] O bom, o mau são somente o produto

5 Reproduzo com este neologismo a tradução da expressão inglesa embodied feita por Eduardo Viveiros de Castro (1996). 
de uma seleção ativa e temporária a ser recomeçada" (Deleuze e Guattari 1995: 18).

\section{O RITUAL}

Enquanto estrutura complexa, o ritual do "namoro" ${ }^{\circ} \mathrm{com}$ as meninas se desdobra ao infinito em possibilidades imprevistas e nos ritos subjacentes, mas não menos importantes, que fazem ao lado do primeiro a substância e o sentido dos símbolos postos em prática. Deste modo, busco aqui a construção de uma estrutura maior contendo três fases principais - as apreendidas pelo discurso de Andrea e Nálary, principalmente -, as quais serão ramificadas e confrontadas pelas falas das outras meninas, mas que ainda assim não chegarão a abarcar a totalidade.

\section{"VAI NAMORAR HOJE?" - APROXIMAÇÃO}

O primeiro momento ritual seria aquele em que é travado o contato inicial entre prostituta e cliente. É, em linhas gerais, a situação em que interesses objetivos, apresentáveis com uma resposta que seria simples, "vou" ou "não vou", são exprimidos, determinando o decorrer dos acontecimentos.

Há, contudo, ao invés de clareza objetiva, jogos intrincados de palavras, gestos e olhares que, imbuídos de uma significação não evidente para uma iniciante no universo da prostituição no Granada, irão possibilitar a continuidade da ação.

A primeira ação ritual a ser analisada é o estabelecimento do contato com fins sexuais. A posição da grande maioria das meninas em relação a isto é de que o homem tem que chamar. ${ }^{7}$ Note-se, contudo, que este chamar não se restringe ao contato verbal. Na verdade, é por meio dos olhares que se entende a aproximação masculina e, por vezes, esses olhares são tão furtivos e de homens tão esquivos que eu não me apercebo nem destes, quanto mais daqueles. Só vou saber quando alguma menina se levanta para encontrá-los ou elas comentam, depois, o motivo de não terem ido.

Independente da minha falta de perspicácia e de interesse em fazer programas, que me deixam meio cega para essas aproximações, é interessante notar que a relação é estritamente delimitada. Ficam homens de um lado, geralmente em pares, bebendo cerveja e colocando músicas no jukebox; e mulheres de outro, mais numerosas, bebendo refrigerante e maquiando-se interminavelmente.

6 Como, por vezes, é chamado o programa.

7 Somente Cassandra se posicionou de forma contrária, dizendo que "se a mulher for mais esperta, chama logo, né? Aí senta, conversa... Uma, duas cervejas, sobe, vai pro quarto e pronto" [nota do dia 20 de outubro de 2010]. 
A situação muda - interagem homens e mulheres, na mesma conversa, na mesma mesa - quando o compromisso de fazer o programa é firmado.

Andrea, ao me contar como deve agir uma menina no Granada para se dar bem, exemplifica:

"Enquanto o homem toma uma cerveja, conversa e pergunta se ele vai namorar ou não. Aí se ele não for tem que sair logo da mesa. Mas se ele disser 'fique aqui que você não perde, e tal, daqui a pouco a gente vai' aí a gente fica mais um pouco. Se vir que ele não quer nada, tem que sair, né? Se for besta fica lá perdendo tempo" [conversa do dia 2 de setembro de 2010].

Deste modo, mesmo as conversas triviais na mesa do bar, os refrigerantes bebidos - ou as cervejas - são parte constituinte do ritual do programa com as meninas. Estas ações só tomarão lugar se houver a expectativa concreta de subir para o quarto em um momento posterior.

Segundo nota do dia 23 de setembro de 2010, Marlene comenta indignada que um cliente seu foi "roubado" por "aquela gorda". Pergunto se era Cassandra a quem ela se referia e ela diz que sim. Explica que Cassandra teria ficado "se botando para seu cliente", olhando para ele, enquanto eles tomavam cerveja, o que culminou na saída dele com a segunda.

É importante perceber, portanto, que enquanto bebem e conversam besteira, as meninas já estão fazendo o programa e, quando este não tem o final bem-sucedido, por conta de outra que "rouba" o cliente, configura-se uma deslealdade, uma transgressão à regra de boa convivência entre elas. Esta situação não ocorre, porém, quando a menina está, por algum motivo, impossibilitada de atender o cliente.

Entendi esta forma de aproximação - o homem chamar para conversar e depois subir para o quarto - como sendo a mais recorrente, principalmente entre os que já estão habituados a frequentar o Granada e, por consequência, o centro de Fortaleza.

Cassandra explica correta e sucintamente os esquemas de aproximação hegemônicos no bar: "Aí, mas quando tão aqui em baixo eles [os clientes] chegam, tomam uma cerveja. Aí observam todas as mulheres, aí chama quem lhe interessa, quem interessar a ele, ele chama."

Há, contudo, como foi advertido acima, muitas formas paralelas que se avultam ao lado desta. Procurarei explanar algumas delas compreendendo a impossibilidade de esgotá-las.

\section{Quando as chamam do carro}

Dona Larice, que há mais de vinte anos vende lanches para as meninas que fazem programa no Granada e Passeio Público (praça histórica que faz face ao bar), comenta que é grande a quantidade de clientes que vêm de carro. 
Suponho que se trate de situações em que os homens chamam as meninas de dentro de seus automóveis como forma de ficarem incógnitos, longe dos olhares acostumados e perspicazes dos frequentadores, funcionários, comerciantes, moto-taxistas e prostitutas que se agrupam na esquina da rua Dr. João Moreira com a rua Major Facundo, seja dentro do bar, na sua calçada, atravessando a rua, ou no carrinho de lanches de Dona Larice.

No período em que fiz etnografia, entretanto, notei poucas abordagens vindas de carros - uma em relação a mim e outra quando uma menina que trabalha na "boate" - denominação nativa para o Espaço Show Bar, que fica ao lado do restaurante Granada pela rua Dr. João Moreira - voltava de um programa.

O meio de transporte se faz desnecessário tanto no bar quanto na boate, uma vez que ambos têm a si incorporados uma área de motel: quartos que podem ser usados para programas em conformidade com os preços praticados no local. Entendo, portanto, o uso de carro como extraordinário e, principalmente, um artifício de clientes iniciantes na dinâmica da prostituição do Passeio Público.

Nota-se que a quebra que o uso do carro implica no ritual tem consequências imediatas. Andrea me contou, por exemplo, a diferença de preço que implica o "desvio" no padrão de programas.

Também Rafaela comenta comigo, no dia 27 de outubro de 2010, que, apesar de seus clientes não serem habitués do bar, eles a procuram majoritariamente a pé. Esta declaração leva-me a estabelecer outra forma paralela de se travar o primeiro contato para a realização de um programa, a qual explano no tópico seguinte.

\section{Quando as chamam pelo telefone}

Rafaela, quanto a seus hábitos ao chegar para fazer o trottoir $^{8}$ e ainda em relação a seus clientes, me explica:

"Rafaela: É, fico logo por aqui mesmo [na calçada tradicionalmente ocupada por Dona Larice]. Meu negócio é por aqui mesmo, meus clientes já sabem que eu só chego esse horário [por volta das 15 horas]. Eu não tenho cliente em bar, eu não me sento em bar. Meus clientes são só esses que chegam mesmo. $[\ldots]$

Pesquisadora: E tu escolhe os clientes?

Rafaela: Escolho. Não saio com cliente bêbado, não saio com cliente drogado. Meus amigos são tudo bom mesmo, só vêm me procurar mesmo e volta, né? Não é cliente de chegar e ficar bebendo [não entendi o final].

8 Como é denominada a prostituição de rua, seja de mulheres, homens ou travestis. Ver melhor em Hélio Silva (2007). 
Só vem pra cá mesmo. Só brincar e namorar mesmo" [nota do dia 2 de setembro de 2010].

Ela usa bastante o telefone - quando estou conversando com ela é difícil não sermos interrompidas uma ou duas vezes com chamadas dos clientes - e esta tecnologia implica em padronizar mais uma forma de "cativar" os amigos. Percebo sempre uma fala arrastada, com termos “água com açúcar” como brincar, namorar e bebê, que fazem parte da característica única que Rafaela assume.

\section{Quando as chamam (ou as seguem) da rua}

A terceira - e última citada, mas não última possível - é a que creio ser a mais frequente das chamadas formas paralelas. Dá-se quando os homens interessados, utilizando um mínimo de contato físico e verbal público com toda a dinâmica da prostituição, fazem as meninas entenderem a sua intenção do programa.

Eles passam pela calçada do bar, olham e seguem para o motel, na maior parte das vezes. A menina, socializada de forma a perceber o mais sutil desses olhares, encaminha-se também para o motel imediatamente. Questões como preço, tipo de serviço e duração podem ser combinadas nos espaços do motel que antecedem o quarto (escada e mesa em que se paga o quarto e a camisinha).

Há os que seguem desde longe as meninas. Ao identificá-las como prostitutas, os clientes caminham atrás delas, às vezes por muitos quarteirões. Elas os percebem e entram no seu jogo até que chegam ao motel e sobem, sem uma palavra trocada anteriormente.

\section{"SÓ FALAM BESTEIRA, MULHER!" - CONVERSA}

O segundo momento ritual a ser observado é aquele em que o programa já está combinado, mas ainda não se subiu para o quarto. Geralmente, dura o tempo que leva para o amigo terminar a sua cerveja. A menina, já "contratada”, lhe faz companhia, aguardando-o, como parte de seu trabalho.

Há uma dupla característica nesta situação em que se estabelece um diálogo entre o cliente e a prostituta. Se, por um lado, questões práticas são resolvidas - o tipo de programa ou a manutenção do programa já acertado -, por outro, estabelece-se uma interação elaboradora de uma mimese do que seria um relacionamento de conotação sexual entre homem e mulher não comercial ou "por apetite".

Este segundo aspecto parece-me o mais interessante, uma vez que seriam discutidas representações do que é considerado um modelo de relacionamento tradicional e, ao mesmo tempo, as pequenas diferenças, nuances quase 
imperceptíveis a um observador externo, que estabelecem os limites diferenciadores indispensáveis entre o sexo "por apetite" e o "programa".

Há, contudo, um grande índice de evasividade nas respostas das meninas quando perguntadas acerca dos "assuntos" que se falam. Como o nome deste tópico sugere, as meninas com quem conversei dão pouca importância ao que é dito. Apesar de, com a insistência da pergunta, algumas fazerem esforço para lembrar-se, este é um assunto que fica enevoado entre as "besteiras" que têm de aguentar na profissão.

Por outro lado, quando querem descrever para mim um bom cliente, ou um cliente com o qual aceitam passar mais que os 10 a 15 minutos tradicionais, elas dizem que o fazem para ficar "só conversando".

Com o tempo e com as conversas fui capaz de perceber que esses duplos de relacionamentos amorosos têm características definidoras, sublinhadas pelas meninas - e segundo seus comentários, às vezes não tanto pelos clientes -, de modo a deixá-los fora de seu repertório de amores, sejam eles "sérios" ou casuais.

Chego à conclusão, neste ponto, de que a pressa - para saber se ele vai fazer ou não o programa, para que ele termine logo a cerveja, para que ele goze logo - avulta-se como a característica mais marcante dos encontros com essas meninas. Claro que esta não é uma regra absoluta, há sempre os "bons clientes" que são escusados desses inconvenientes do relógio e podem tornar-se mesmo namorados, mas, como se percebe, eles são a exceção.

\section{"E AÍ, VAMO?", “EITA, MULHER!" - SEXO}

Levantam-se, saem do bar e seguem por uns poucos dez metros até a porta do motel. Ao adentrar, deparam logo com uma escada visível da rua, feita com degraus altos e uma cerâmica de cor entre bege e telha. Sobe-se um lance, no qual se devem contar uns vinte degraus. No andar superior, tem-se o Juarez, sentado em um birô, num ambiente iluminado por luz natural, com alguns objetos em cima da mesa. É ele quem recebe o dinheiro - cinco reais pelo quarto, um real pela camisinha -, e dá a chave e o preservativo.

Há duas possibilidades de espaços a partir da mesa do Juarez, que fica em uma espécie de hall. Pode-se seguir em direção leste, encontrando um corredor iluminado como o ambiente anterior, no qual estão dispostos uns seis quartos. Pode-se também seguir oeste, entrando num ambiente mais escuro e no qual, pela forma menos organizada (as portas não ficam emparelhadas como no outro), tem-se uma sensação de reforma mal planejada. Neste há mais dois quartos, os quais são maiores, mais arrumados e, portanto, mais caros (custam seis reais). Deste segundo espaço, vê-se uma escada em espiral que dá para o interior do bar, interligando os ambientes. Imagino que esta escada tenha utilidade para os funcionários (a Tia da limpeza, por exemplo; já as meninas nunca a usam). 
As meninas contam que quando chegam ao birô do Juarez pedem logo o quarto e a camisinha, para que o homem não queira evitar o uso dela. No dia 15 de outubro de 2010, Andrea conta que o quarto custava sete reais, ficando um para a menina e seis para o estabelecimento. Atualmente, contudo, o preço baixou para cinco reais, e este benefício, que funcionava como uma comissão, não existe mais. As meninas restringem seus ganhos ao valor acertado com o cliente. $^{9}$

Em motéis, o preço geralmente é condicionado ao tempo que se passa no quarto. Como elas - estávamos na mesa Andrea, Nálary e eu - não mencionaram este fator enquanto expunham as mudanças no sistema, coloquei esta questão, percebendo contente que a resposta trouxe exposições de importantes símbolos que compõem este complexo ritual secular.

"Perguntei então se esses seis reais tinham um tempo certo. Elas disseram-me que se podia ficar por até uma hora, mas que elas terminavam tudo em 15 minutos, contando com banho antes e depois. Achei interessante e remarquei que elas, realmente, estavam sempre de cabelo molhado" [nota do dia 15 de outubro de 2010].

Estes símbolos estão ligados ao palco em que são postos em ação. O quarto do motel representa neste ritual um espaço liminar. O é porque, entendendo, como Turner (2005), que a "liminaridade" se configura pela posição interestrutural, a construção social deste espaço específico ambientará o ápice da fabricação do relacionamento amoroso entre os que, há pouco, eram meros desconhecidos.

Encontro neste processo ritual de criação do íntimo - que tem seu ponto máximo na transa -, portanto, a substância que doa coerência e inteligibilidade à prática da prostituição enquanto profissão para as meninas do Granada. É um íntimo próprio ao corpo, um íntimo cerceado por quatro paredes e 15 minutos. É o íntimo dos corpos buscado pelos homens, expressado em prazer sexual dos homens e a todo momento simulado e fabricado pelas meninas (mulheres!). Recria-se, portanto, um ambiente doméstico, na medida em que o sexo está ligado a ele, dentro de um ambiente público, na medida em que as práticas comerciais se impõem.

As estruturas que marginalizam - mas que ao mesmo tempo se penetram - nesta prática seriam as que se configuram em categorias primordiais da sociedade mais abrangente. O doméstico e o mundano, fundidos no quarto do

9 Há, contudo, casos de furtos em que elas "se pagam” melhor. Andrea contou-me dois casos de furtos: "no segundo estavam ela, Cassandra e Nálary fazendo o programa com um homem. Enquanto Nálary dava banho nele, no banheiro, ela vigiava a porta e Cassandra olhava os bolsos. O homem havia dado 50 reais para dividir pelas três. Cassandra pegou mais 50 reais para cada uma" [nota de 27 de outubro 2010$]$. 
motel, são os mesmos atributos paradoxais que carregam as meninas. Elas não são somente produto do liminar, elas o produzem.

Nesta produção, eu entendo a participação masculina como coadjuvante. Eles seriam, mal comparando, o sacrificante de Marcel Mauss e Henri Hubert (2005). Ele é elemento essencial na performance ritual, ele é mesmo o animador da instituição que restaria como que adormecida - na verdade sentada nas cadeiras duras do Granada, tomando um sorvete ou fumando um cigarro -, aguardando a sua chegada.

É o seu trânsito, adentrando e saindo dos círculos que, neste caso, não são sagrados, apesar de fortemente delimitados estruturalmente, que o faz coadjuvante. Na tradição ocidental (Sallmann 2010; Rago; 2008; Pasini 2009) ao homem é condescendentemente permitido circular entre os meios de prostituição sem ser associado definitivamente a eles. Ele pode ir e vir, mesmo que vá e venha com muita frequência. ${ }^{10}$

As meninas que, com seus corpos e seus espíritos, ambos maquiados para recebê-los, os satisfazem em seu desejo transgressor, não têm a mesma mobilidade. As duras fronteiras que lhes são impostas enquanto mulheres não permitem aos olhos dos outros e aos de si mesmas tanta complacência.

A posição liminar é assumida interna e externamente. ${ }^{11}$ Pode-se "largar a vida" e, pode-se largá-la completamente, mas como acontece com Catarina (que passou alguns dias naquele espaço dada uma vinda ocasional à cidade), muitas delas, mesmo casadas e empregadas, retornam ao lugar no qual a independência começou a ser buscada e onde a cumplicidade, mesmo que as meninas sejam outras, ainda pode ser sentida.

Eliana Calligaris (2006: 60), em Prostituição: O Eterno Feminino, propõe: "É interessante pensar na origem da palavra prostituição, que segundo Bloch e Warburg, vem do latim prostituere que significa 'expor livremente'". Essa exposição livre, se pensada na perspectiva das meninas, relacionar-se-ia ao uso do corpo e da sexualidade segundo práticas comerciais, que se afastariam do relacionamento monogâmico compreendido enquanto forma dominante de vivência da sexualidade na sociedade mais abrangente. O paradoxo decorrente desse uso, contudo, é resolvido quando as meninas ritualizam as relações sexuais que mantêm com seus clientes, delimitando-as e afastando-as de suas experiências com parceiros não comerciais.

A produção do íntimo no quarto não visa uma mimese perfeita. As meninas quase nunca querem se "entregar", os amigos nem sempre querem o "feijão com arroz". Por vezes, além do desejo por sexo em si, existe o desejo por especificidades fetichistas (como quando elas "comem" os clientes com o auxílio de

10 "O frequentador é aquele que tem a possibilidade do movimento, da transitoriedade. [...] também é um elemento que constitui o contexto estudado” (Pasini 2009: 242).

l 1 Para “no caso da mulher, que 'honestas' e 'perdidas' não se confundissem” (Rago 2008: 29). 
vibradores) que só poderiam ser satisfeitas, sem macular a identidade masculina que as construções de gênero correntes por eles assumidas lhes atribuem, em um ambiente liminar, com meninas liminares. ${ }^{12}$

É enquanto espaço eminentemente liminar, portanto, que o quarto se configura como palco em que os ritos têm de ser mais claros e determinantes. Num ambiente no qual se poderia fazer tudo, é muito importante que se ritualize o que se vai fazer. Como preleciona Mary Douglas (1976: 119), “o perigo está nos estados de transição", no limbo em que não se tem certeza de nada, e "o perigo é controlado por um ritual". Para além da teoria, este é um fato importante porque, dada a inobservância de algum rito, dependendo da menina, pode haver a não consumação do programa.

Os ritos praticados pelas meninas no quarto do motel (assimilados pela presença, naturalidade, ênfase, etc., nas falas, em razão de que não foram por mim presenciados) podem ser classificados como ritos de pureza, ou não contaminação, física e moral. Estes foram divididos nos tópicos abaixo.

\section{Da assepsia}

Como propus na nota citada anteriormente, é interessante observar que as meninas estão muitas vezes de cabelos molhados, banhadas há pouco tempo em decorrência de um programa feito recentemente ou mesmo para atrair os clientes. Importa notar que o cabelo molhado aqui é tanto prova de sua assepsia e exemplo a ser seguido pelos clientes quanto uma forma de convite ao programa. Os cabelos molhados estão ligados, ainda, a um atributo positivo do bom cliente, que é representado frequentemente como um homem cheiroso.

Do amigo, portanto, espera-se também o asseio. Continuando no exame das notas do dia 15 de outubro, a questão dos banhos - contados no tempo despendido no quarto do motel como parte integrante do programa - é abordada novamente:

"Perguntei se os clientes tomavam banho também. Elas disseram que sim, que pediam para eles tomarem. Havia os que não queriam, mas elas insistiam, e ainda assim, alguns 'limpavam a rola só assim' [Andrea imitou um homem fazendo um círculo com os dedos indicador e opositor e percorrendo-o ao logo de um pênis imaginário] e que quando iam colocar a camisinha 'só vinha o preto'. Neste caso elas mandavam lavar direito, que não colocariam aquilo no 'periquito' delas, 'imagina se estoura a camisinha'".

12 "A sexualidade de um sujeito não é previamente ou naturalmente estabelecida e de forma alguma está fixa em um corpo, em uma maneira de ser e de se expressar. Por tudo isso, ela só adquirirá significado quando compreendida sob um determinado contexto cultural e histórico, a partir de uma situação específica, a partir dos sentidos ali elaborados" (Pasini 2009: 244). 


\section{Da camisinha e a questão da ereção}

Após o banho têm início as práticas diretamente ligadas à cópula. Duas questões sobressaem: a ereção e o uso da camisinha. Estes elementos aparecem de forma imbricada e são determinantes no desfecho do ritual. Nálary e Andrea garantem só fazer com camisinha, inclusive no caso de sexo oral. Todas as meninas com quem conversei disseram o mesmo. As primeiras, contudo, a despeito de suas próprias práticas, relatam que são minoria, que existem muitas que fazem sem camisinha e, deste modo, acostumam mal os clientes.

A camisinha aparece como objeto importante tanto na sua presença quanto na sua ausência. O grau de exigência do seu uso por parte das meninas promove uma divisão de estilos de programas e, portanto, de clientes - inclusive migrações destes.

Importa notar uma questão prática: ela só pode ser colocada com o pênis ereto - devendo para isso o homem estar bastante excitado - e, dadas as particularidades do programa, as preliminares são bastante limitadas. Isto se dá porque, como será visto posteriormente, o contato físico entre prostituta e cliente será reduzido ao mínimo possível na maior parte das vezes.

Quando perguntei a Andrea pela questão da ereção, necessária para que fosse possível colocar a camisinha, ela contou-me que a maioria já saía do banheiro "de pau duro". A outra opção foi logo o caso de serem "brochas" impotentes -, caso no qual elas não teriam nada a fazer. Tentei retomar o meio termo e ela deixou vaga a ideia de masturbá-los.

Já Cassandra expõe bem as ações requeridas para excitar o cliente em conversa do dia 20 de outubro:

“Às vezes eles já saem de dentro do banheiro, eles já vêm tão na tara, sem o... Ah, quando vem de pau mole você tem que bater punheta, ou então você pega a camisinha, quando tá de pau mole, eu boto na boca, aí deixo a camisinha na boca e chupo o pau dele até endurecer. Mas tem deles que já vêm tão na tara de transar que saem do banheiro já loucos, já".

\section{Dos beijos e do contato físico}

Os limites relacionados a beijos na boca e contato físico em geral são a mais clara e homogênea característica definidora do programa. Todas as meninas têm limites relacionados ao contato físico com os clientes e aqueles costumam ser parecidos. A ressalva em relação aos bons clientes - que muitas vezes tornam-se namorados ou maridos - permite-nos imaginar a quebra de algumas dessas regras de pureza.

Com as várias conversas, algumas gravadas, outras anotadas, e mesmo memórias de campo reduzidas a tópicos sumários, deparo com representações de muitas meninas sobre o assunto. Nas suas falas e, em consequência, neste texto, os carinhos - ou a falta deles - são assumidos como forma mais 
importante de distinção entre o sexo não pago e o programa. Pode-se, deste modo, elaborar um panorama dos afetos permitidos, consentidos, necessários e desejados no contexto da prostituição.

Valdete explica: "Aí, quando eu tô com as perna aberta ele fica batendo punheta e olhando pro meu bicho. Aí eu fico mexendo no pinguelo, ${ }^{13}$ balançando. Aí ele pega, bota a camisinha, aí ele mete, né?" Sua fala é reveladora, dado o posicionamento do efêmero casal. A despeito da cena amplamente veiculada nas produções midiáticas - tradicionais e pornográficas (Díaz-Benítez 2010) -, os corpos aparecem aqui desprovidos do contato físico. O estímulo masculino será feito pela masturbação enquanto Valdete simularia o mesmo.

Enquanto a primeira ação tem por intenção o estímulo ou mesmo a satisfação do desejo sexual, a segunda tem como propósito primeiro estimular o desejo masculino pela simulação do estímulo do desejo feminino. Se a menina fica ou não, de fato, com "tesão", pouco importará em um programa. É necessário apenas que ela o simule como mais um aspecto do duplo imperfeito da relação "por apetite" que começa a ser criado desde que é estabelecido entre as partes que o programa será feito. ${ }^{14}$

Certa vez perguntei a Andrea e a Nálary se elas gozavam quando faziam programa. Andrea soltou um enfático "nem!", mas depois ponderou que se estivesse "há uns três dias sem gozar e se o homem metesse bem..." Contou também que Nálary certa vez descera do quarto "tremendo as pernas" - por haver gozado.

As duas terminaram a conversa, contudo, dizendo que mesmo em uma situação extraordinária de um "cliente cheiroso que mete bem" evitavam gozar, seguravam o gozo (e não o retardavam como fazem os homens para prolongá-lo), de modo a não sentir o ápice do prazer sexual.

Não nego que, ao escutá-las, considerei esta atitude inútil e um tanto estoica. Entendi a dimensão de pureza, mas considerei-a tributária a um nível de um machismo que eu considerava superado em relação às práticas sexuais das meninas. Seria esta moral vitoriana (Foucault 1988) tão enraizada que, em plena prática do sexo ilícito, proibisse o gozo?

Não muito mais tarde pude perceber, porém, que este gozo está intimamente relacionado aos afetos, ao carinho e, principalmente, ao desejo (delas). Enquanto não gozam, as meninas não ficam tão vulneráveis ao envolvimento com homens indesejáveis. O gozo apresenta na fala das meninas algo ainda romantizado, ele é guardado para os seus amores ou, melhor dizendo, seus

13 Clitóris.

14 Como propõe Margareth Rago (2008: 30) em Os Prazeres da Noite: "Mais do que qualquer outra, a prostituta é uma projeção do freguês e, como tal, sua função consiste em representar o teatro que lhe é encomendado". 
amores-próprios, estejam eles imbricados com um ideal de relação romântico-sexual ou não.

Este amor se configura, portanto, como o falso cognato do artigo à venda entre as meninas do Granada. O que elas oferecem é proporcionar prazer ao homem que as procura, e isto não é feito senão através de uma complexa ritualização que as afaste emocional e fisicamente deste prazer e destes não-homens. Deste modo, quando conversávamos, eu Andrea e Rafaela, esta explicou-me:

"Que lá os homens não ficavam pegando em mulher nenhuma. Que elas [as prostitutas em geral], quando começam a 'vida', pensam que os homens vão ficar pegando na perna delas, esse tipo de coisa, mas que não acontece. Rafaela completou que às vezes nem mesmo no quarto há muito contato, eventualmente ela dá um jeito para que eles nem peguem em seus peitos, alisando o rosto do cliente na hora do ato sexual. Andrea concorda e diz que não deixa eles pegarem, a não ser que seja um cliente legal, mas que esses 'cafuçus' [homens de baixo calão] ela não deixa, não" [nota do dia 27 de outubro de 2010].

É importante, portanto, perceber que mesmo os contatos que são considerados "intrínsecos" ao ato sexual, como carícias no corpo, principalmente seios e nádegas, são raramente permitidos. Há uma restrição, tanto quanto for possível, do sexo aos órgãos genitais. Andrea mencionou certa vez que, com os clientes, preferia a posição "por trás" porque evita de forma eficaz beijos e mesmo o contato físico de um corpo com o outro.

Manuela conta: "Não, tem negócio de se esfregar não. Endureceu, já sento em cima ou ele senta em cima de mim e pronto. Tem negócio de alisado não, que ele não é meu namorado". Sempre que lhes perguntava o que era diferente quando não era com um cliente, a resposta constante era o rosto iluminar-se e uma divertida resposta dizendo que mudava "tudo". Que quando elas gostam, "aí é muito diferente, a gente abraça, beija, faz carinho".

\section{Do dinheiro}

De acordo com Mary Douglas (1976: 88), “[o] ritual torna visíveis sinais exteriores de estados interiores. O dinheiro medeia as transações, o ritual medeia a experiência, inclusive a experiência social".

Considero esta passagem duplamente interessante. Em primeiro lugar, porque elucida a importância de observar os símbolos rituais para conhecer sentimentos e representações sociais de outro modo inexprimíveis. Em segundo lugar, porém, a analogia que Douglas faz do ritual com o dinheiro, o qual seria "somente um tipo extremo e especializado de ritual" (1976: 88), remete a um dos elementos determinantes para que se configure o ritual que descrevo. 
É certo que o dinheiro não é o único elemento que caracteriza o "sexo" com prostitutas. Como foi proposto acima, existem vários ritos de pureza que o delimitam. Importa, contudo, situá-lo enquanto um símbolo desencadeador deste ritual sexual. A diferença primeira entre o programa e o sexo "por apetite", os dois modelos de relação contrastados nessa análise, é o pagamento.

Tal se dá porque o homem, ao procurar a relação sexual paga, desencadeia a ação ritual proposta, inscrevendo-se em espaços liminares com meninas liminares que lhes proporcionarão outro tipo de sexo (um não-sexo), mesmo que as formas ditas "fetichistas" 15 não sejam acionadas. ${ }^{16}$

Importa observar o dinheiro como símbolo dominante (Turner 2005), desencadeador e, portanto, determinador da ação. Sua presença faz com que o ritual do programa com as meninas e todas as suas especificidades seja posto em cena. Quando o dinheiro desaparece, contudo, outro tipo de papel é por elas assumido, o papel da amante, da namorada, da esposa, que apesar de similar ao da prostituta em relação ao "fazer sexo", é diametralmente oposto na significação e na prática deste sexo, que de tão afastado é não-sexo, é programa.

Continuando este raciocínio, o dinheiro, enquanto símbolo dominante, suscita ações que produzem liminaridade. Esta, do modo como é aqui proposta, refere-se à posição entre, sobretudo, o cansaço da rotina cotidiana, que mesmo a ambiência no centro de Fortaleza pode demonstrar, e a produção da festa, apreendida pela inscrição do bar nestes horários de trabalho - fica aberto das 8 da manhã às 8 da noite, aproximadamente.

"A transgressão erótica parece, por isso, algo de diferente e irredutível, tanto à obediência da tradição como à inovação revolucionária; ela é uma passagem do momento profano do trabalho e da fadiga cotidiana ao momento sagrado do sacrifício e da festa. A sociedade é composta simultaneamente por ambos os momentos: a suspensão do tabu na experiência erótica configura-se portanto como um trânsito do mesmo para o mesmo" (Perniola 2000: 64).

Ao se dispensar o dinheiro enquanto símbolo dominante, portanto, estabelece-se uma relação instituída em um domínio socialmente reconhecido, seja

15 Como exemplos se têm a sodomização do cliente pela prostituta, atrás referida, e a prática deles de cheirar suas calcinhas, mencionadas em conversas.

16 Como Elisiane Pasini (2009: 246), em seu texto "Sexo com prostitutas: uma discussão sobre modelos de masculinos", entendo que "a possibilidade de realizar diferentes práticas sexuais com prostitutas era um importante motivador para a sua presença na Vila. No entanto [...] estas 'práticas diferentes’ poderão adquirir outras conceções e significados". 
ele o do namoro ou do casamento, que exige outras formas padronizadas de se relacionar. $\mathrm{O}$ trânsito definitivo para o doméstico - abolindo a dimensão comercial do sexo - é comumente visto no bar.

Numa circularidade percebo que, quando é estabelecida a realização do programa, o preço costuma ser, na fala das meninas, a primeira demanda a ser discutida com os amigos. O pagamento de fato, contudo, costuma ser o último rito a ser realizado, fechando, deste modo, o processo ritual.

Terminando este artigo, cedo a palavra a Marlene, que, de forma divertida e bem significativa, conta o caso de um cliente, fazendo uma projeção em relação a si mesma e assumindo na estrutura complexa de sua fala as grandes contradições vividas que, no final das contas, lhe dão motivos de risada:

"Tem uns que pagam primeiro, tem outros que pagam depois, quando termina o serviço. Aí, eles dão. Agora, tem uns que faz questão, 'Pega, guarda logo o teu, porque uma vez eu tava lá no ponto de ônibus, esqueci de pagar a mulher e a mulher ficou dando: 'fiu, fiu, vem cá', na frente de todo mundo! Eu fiquei passado. Aí agora, na hora que entrar eu dou logo!' [risos] É, mulher, acontece... Tu pensa que é só a mulher que passa vergonha? Os homens também! Os homens não gostam de escândalo, não. Pagar meu programa na parada do ônibus, na frente de todo mundo? Ele arrasou, né?" 


\section{BIBLIOGRAFIA}

CALligaris, Eliana dos Reis, 2006, Prostituição: O Eterno Feminino. São Paulo, Escuta.

CASTRO, Eduardo Viveiros de, 1996, "Os pronomes cosmológicos e o perspectivismo ameríndio", Mana, 2 (2): 115-144.

DAWSEY, John C., 2005, “O teatro dos 'boias-frias': repensando a antropologia da performance”, Horizontes Antropológicos, 11 (24): 15-34.

DELEUZE, Gilles, e Félix GUATTARI, 1995, Mil Platôs: Capitalismo e Esquizofrenia, vol. 1. São Paulo, Editora 34.

DíAZ-BEníteZ, María Elvira, 2010, Nas Redes do Sexo: Os Bastidores do Pornô Brasileiro. Rio de Janeiro, Zahar.

DOUGlaS, Mary, 1976, Pureza e Perigo. São Paulo, Editora Perspectiva.

FAUSTO, Carlos, 2002, "Banquete de gente: comensalidade e canibalismo na Amazônia", Mana, 8 (2): 7-44.

FOUCAUlT, Michel, 1988, História da Sexualidade I: A Vontade de Saber. Rio de Janeiro, Edições Graal.

GIRARD, René, 1990, A Violência e o Sagrado. São Paulo, Editora Universidade Estadual Paulista.

HOUSEMAN, Michael, 2004, “The red and the black”, Social Analysis, 48 (2): 75-97.

LUNA SAleS, Ana Paula, 2011, Amor à Venda? Uma Etnografia da Prostituição no Restaurante Granada. Fortaleza, Centro de Humanidades, Universidade Estadual do Ceará, monografia para a obtenção do título de bacharel em Ciências Sociais.

MAUSS, Marcel, e Henri HUBERT, 2005, Sobre o Sacrifício. São Paulo, Cosac Naify.

OLIVAR, José Miguel Nieto, 201 1, "Banquete de homens. Sexualidade, parentesco e predação na prática da prostituição feminina”, Revista Brasileira de Ciências Sociais, 26 (75): 89-101.

PASINI, Elisiane, 2009, "Sexo com prostitutas: uma discussão sobre modelos de masculinos”, em María Elvira Díaz-Benítez e Carlos Eduardo Fígari (orgs.), Prazeres Dissidentes. Rio de Janeiro, Garamond, 237-363.

Perniola, Mario, 2000, Pensando o Ritual: Sexualidade, Morte, Mundo. São Paulo, Studio Nobel.

RAGO, Margareth, 2008, Os Prazeres da Noite: Prostituição e Códigos da Sexualidade Feminina em São Paulo, 1890-1930. São Paulo, Paz e Terra (2. ${ }^{a}$ edição).

SALLMANN, Jolanda, 2010, "Living with stigma: woman's experience of prostitution and substance use”, Affilia: Journal of Women and Social Work, 25 (2): 146-159.

SILVA, Hélio R. S., 2007, Travestis: Entre o Espelho e a Rua. Rio de Janeiro, Rocco.

STRATHERn, Marilyn, 1988, The Gender of the Gift: Problems with Women and Problems with Society in Melanesia. Berkeley, Los Angeles e Londres, University of California Press.

TURNER, Victor, 2005, Floresta de Símbolos: Aspectos do Ritual Ndembu. Niterói, Editora da Universidade Federal Fluminense. 